\title{
Stavovi medicinskih sestara i pacijenata o vidljivim tetovažama
}

\section{Attitudes of nurses and patients about visible tattoos}

\author{
Ivana Crevar' , Radoslav Kosic 2,3 \\ ${ }^{1}$ Medicinska škola Karlovac, Andrije Štampara bb, 47 000, Karlovac, Hrvatska / Medical School Karlovac, Andrije Štampara bb, 47000 Karlovac, Croatia \\ e-mail: crevar.ivana@gmail.com \\ ${ }^{2}$ Klinički Bolnički centar Rijeka, Klinika za pedijatriju, Istarska 43, 51000 Rijeka, Hrvatska / University Hospital Center Rijeka, Clinic for pediatric, Istarska 43, \\ 51000 Rijeka, Croatia \\ ${ }^{3}$ Fakultet zdravstvenih studija Rijeka, Sveučilište Rijeka, Viktora cara Emina 5, 51000 Rijeka, Hrvatska/ Faculty of Health Studies Rijeka, University of Rijeka, \\ Viktora cara Emina 5, 51000 Rijeka, Croatia \\ e-mail: radoslav.kosic@uniri.hr
}

\section{Sažetak}

Cilj: Cilj je istraživanja ispitati i usporediti stavove medicinskih sestara i pacijenata 0 vidljivim tetovažama na tijelu.

Ispitanici i metode: $U$ istraživanju je sudjelovalo 88 ispitanika (42 medicinske sestre i 46 pacijenata). Istraživanje je provedeno u Službi za internu medicinu Opće bolnice Karlovac. Formiran je prigodni uzorak i kriterij je bio punoljetnost. Korišten je anketni upitnik. Prvi dio upitnika sastoji se od pitanja o sociodemografskim podacima: spol, dob, stručna sprema i mjesto stanovanja. Drugi dio upitnika sadrži stavove ispitanika o tetovažama. Treći dio sastoji se od sedam izjava o pacijentima i medicinskim sestrama s tetovažom koje su ispitanici ocjenjivali u rasponu od 1 do 5 te od šest tvrdnji na koje su ispitanici odgovarali s točno/netočno.

Rezultati: Medicinske sestre imaju pozitivniji stav prema pacijentima s tetovažom od pacijenata prema medicinskim sestrama s tetovažom. Ne postoje razlike u stavovima o tetoviranim osobama s obzirom na posjedovanje tjelesne tetovaže ispitanika, stručnu spremu i mjesto stanovanja.

Zaključak: Medicinske sestre odobravaju tetovaže na pacijentima, dok su mišljenja pacijenata podijeljena. Generalno su pozitivni stavovi o tetovažama obiju skupina ispitanika.

Ključne riječi: medicinska sestra, pacijent, vidljive tetovaže, pozitivan stav, negativan stav

Kratak naslov: Vidljive tetovaže

\begin{abstract}
Aim: This study aims to examine and compare the attitudes of nurses and patients about visible body tattoos.

Subjects and Methods: In the study participated 88 subjects (42 nurses and 46 patients). The research was conducted within the Department of Internal Medicine of the General Hospital Karlovac. Respondents were selected at random and the only criterion was that the person was an adult. A three-part questionnaire was used for the research. The first part of the questionnaire consists of questions on sociodemographic data that included questions related to gender, age, education and place of residence. The second part of the questionnaire contains respondents' opinions about tattoos. The third part consists of seven statements about patients and nurses with tattoos that the respondents rated in the range of 1 to 5 and of six statements to which the respondents answered with true/false.
\end{abstract}

Results: Nurses have a more positive attitude toward tattooed patients than patients toward tattooed nurses. There are no significant differences in attitudes about tattooed persons with concerning the subject's body tattoo, education and place of residence.

Conclusion: The results of the research show that nurses approve tattoos on patients, while opinions among patients are divided. Overall, there are generally positive attitudes about tattoos in both groups of respondents.

Keywords: nurse, patient, visible tattoos, positive attitude, negative attitude Runing head: Visible tattoos

\section{Uvod}

Tetoviranje kao oblik umjetnosti društvu je poznato od davnina. Vrijeme u kojemu živimo potvrđuje da je tetoviranje doseglo vrhunac popularnosti osobito među mlađim generacijama [1]. Riječ tatauiranje ili tetoviranje dolazi od tahićanske riječi tatau, što znači tuckati [2]. Riječ tattoo spominje se prvi put u brodskom dnevniku kapetana Jamesa Cooka. Tradicija tetoviranja u Hrvatskoj seže iz 17. stoljeća. Prema ovom narodnom običaju naziv za tetoviranje je sicanje. Na području između Sinja i Šibenika tetovirale su se žene katolkinje radi zaštite od Turaka. Tetoviranje je služilo za obranu časti, ali i života mladih žena katolkinja [3]. Motivi današnjih tetovaža najčešće su povezani s modnim kretanjima [4]. Rezultati brojnih studija navode da su razlozi tetoviranja kod muškaraca sklonost identifikacije s određenom grupom i praćenje modnih zbivanja. Prema studiji Burgera i Finkela glavni razlog za tetoviranje je povećanje samopoštovanja. U njihovu istraživanju muški ispitanici navode da se s tetovažom osjećaju puno privlačnije, dok žene navode 
da se tetoviraju kako bi istaknule seksualnost i individualnost [5]. Starija istraživanja povezana s razlozima tetoviranja uglavnom su provedena među zatvorenicima, psihijatrijskim bolesnicima, vojnicima i osobama ovisnima o opijatima te je u njima tražena i uglavnom dokazana psihijatrijska patologija [5]. Razlozi tetoviranja različiti su, najčešće osobni, a ponekad se tetoviranje obavlja iz zdravstvenih razloga, primjerice, u rekonstrukcijskoj medicini (bradavice kod odstranjenja dojke) ili kod prikrivanja ožiljaka [3]. U novije vrijeme tetovaže su postale oblik društvenog brendiranja koji gotovo uvijek izaziva emocionalnu reakciju, bilo pozitivnu ili negativnu. Rezultati brojnih istraživanja pokazuju da su tetovirane osobe ekstrovertiranije od netetoviranih te imaju veću potrebu za izražavanjem osobnosti [6].

Prioritetni zadatak u sestrinskoj profesiji je posjedovanje potrebnih kompetencija u pružanju sestrinske skrbi. Vrlo važna komponenta u uspostavi dobrih odnosa između zdravstvenih djelatnika i pacijenata jest povjerenje. Na temelju vanjskog izgleda medicinskih sestara i tehničara pacijenti često stvaraju mišljenja i stavove o njima, kako pozitivne tako i negativne. lako se u pravilnicima ne spominje zabrana tetoviranja, pojedinim su poslodavcima tetovaže na vidljivim mjestima jedan od kriterija prilikom zaposlenja [7]. Bez obzira na sve češću pojavu tetoviranja, još uvijek su prisutne predrasude prema tetoviranim osobama i osobama koje nose ukrase ili označavaju svoje tijelo različitim nakitom. Navedeno potvrđuje i podatak da se tek u novije vrijeme u psihologiji počela mijenjati klasifikacija ljudi koji su okarakterizirani kao društveno neprihvatljivi i problematični u društveno prihvatljive. Prema statistikama šest od deset ljudi nasumce odabranih na nekom javnom mjestu ima neku vrstu tjelesnog ukrasa na vidljivom ili manje vidljivom mjestu na tijelu [8].

\section{Ciljevi istraživanja}

Glavni je cilj istraživanja usporedba stavova medicinskih sestara i pacijenata o vidljivim tjelesnim tetovažama.

Specifični se ciljevi odnose na prikaz stavova medicinskih sestara i pacijenata o vidljivim tjelesnim tetovažama ovisno o: spolu, dobi, stručnoj spremi, mjestu stanovanja te o tome ima li ispitanik tetovažu.

\section{Hipoteze}

Hipoteza 1: Medicinske sestre imaju pozitivniji stav prema pacijentima s tetovažom od pacijenata prema medicinskim sestrama s tetovažom.

Hipoteza 2: Pacijenti s jednom tetovažom ili više tetovaža imaju pozitivniji stav prema medicinskim sestrama s tetovažom od pacijenata koji nemaju tetovažu.

Hipoteza 3: Pacijenti s višom ili visokom stručnom spremom imaju pozitivniji stav prema medicinskim sestrama $s$ tetovažom od pacijenata koji imaju srednju stručnu spremu ili su kvalificirani/nekvalificirani radnici.

Hipoteza 4: Ispitanici koji žive u gradu imaju pozitivniji stav prema pacijentima ili medicinskim sestrama s tetovažom od onih koji žive u predgrađu ili na selu.

\section{Ispitanici i metode}

Istraživanje je provedeno u Općoj bolnici Karlovac u rujnu 2020. godine. Istraživanju je pristupilo 46 pacijenata i 42 medicinske sestre unutar Službe za internu medicinu. Ispitanici su odabrani nasumično, a kriterij je bila punoljetnost. Ispitanici su bili upoznati sa svrhom istraživanja te su potpisali Informirani pristanak. Dobivena je suglasnost Etičkog povjerenstva za provođenje istraživanja. Za potrebe istraživanja koristio se anketni upitnik koji je preuzet uz pisanu dozvolu autorice Ines Čordaš [16]. Prvi dio upitnika odnosi se na sociodemografske podatke, drugi dio na mišljenje o tetovažama, treći dio sadrži sedam izjava o pacijentima i medicinskim sestrama s tetovažom i šest tvrdnji koje se odnose na znanje o tetovažama. Ispitanici su na Likertovoj skali (od 1 do 5) trebali zaokružiti broj koji označava u kojoj se mjeri slažu s pojedinom tvrdnjom, dok su na pojedine tvrdnje odgovarali s točno/netočno. Za testiranje postavljenih hipoteza korišten je hi-kvadrat test, uzeta je statistička značajnost na razini $p<0,05$. Analizirano je postoji li statistički značajna razlika između opaženih i očekivanih frekvencija. Prikaz je rezultata tekstualni. Statistička analiza dobivenih podataka napravljena je primjenom programskog paketa Statistical Package for the Social Sciences (SPSS) verzija 19.0 .

\section{Rezultati}

U istraživanju je sudjelovalo 46 pacijenata i 42 medicinske sestre Opće bolnice Karlovac Službe za internu medicinu. Među pacijentima gotovo je podjednak broj žena (52 \%) i muškaraca (48 \%). Među medicinskim sestrama veći je udio medicinskih sestara (88 \%) nego medicinskih tehničara (12 $\%)$. Najveći je udio pacijenata u dobnoj skupini iznad 60 godina (80 \%), manji udio u dobnim skupinama 50 - 59 (9\%) i 40 - 49 godina (11\%). Medijan dobi pacijenata iznosi 69 godina. Medicinskih sestara / tehničara najviše je u dobnoj skupini 40 - 49 (36\%), potom 50 - 59 (24\%), 18 - 29 (21\%), 30 - 39 (12\%) te iznad 60 godina (7\%). Medijan dobi iznosi 45 godina.

Najveći broj pacijenata ima srednju stručnu spremu (61 \%), nekvalificiranih i kvalificiranih radnika je $28 \%$, visoku stručnu spremu ima $9 \%$, a višu $2 \%$. Najviše je medicinskih sestara sa srednjom stručnom spremom (57\%), zatim slijede prvostupnici sestrinstva ( $26 \%$ ), a onih sa završenim diplomskim studijem ukupno je $17 \%$. Najviše pacijenata dolazi sa sela (54\%), iz predgrađa dolazi ukupno $22 \%$ pacijenata, a iz grada $24 \%$. Najviše medicinskih sestara živi u gradu (48 \%), potom na selu (31 \%) i u predgrađu (21\%).

- Na pitanje Imate li tetovažu? najviše je pacijenata odgovorilo da nema i ne želi tetovažu (83\%), 2 \% pacijenata razmišlja o tetoviranju, $15 \%$ ih ima tetovažu, $11 \%$ ima jednu, a $4 \%$ pacijenata ima više tetovaža. Najveći broj medicinskih sestara u istraživanju nema i ne želi tetovažu (66 \%), ukupno $24 \%$ njih razmišlja o tetoviranju, 10 $\%$ ima tetovažu, $5 \%$ ima jednu te $5 \%$ ima više tetovaža.

- Dvije trećine pacijenata ne pridaju pažnju tomu imaju li medicinske sestre koje o njima brinu tetovažu (67\%). Više od petine pacijenata osjeća opuštenost po tom pi- 
tanju (22 \%). Ukupno $9 \%$ pacijenata u istraživanju osjećalo bi nelagodu ili nevjericu, a $2 \%$ ne bi htjelo da im tetovirana medicinska sestra prilazi. Među ispitanim medicinskim sestrama nitko nije izrazio negativne osjećaje prema tetoviranim pacijentima. Ukupno $12 \%$ njih osjeća opuštenost, a $88 \%$ tomu ne pridaje pažnju. Za odgovore na tvrdnju Kada bi se o meni brinula/brinuo medicinska sestra / medicinski tehničar koji ima tetovažu osjećao/ osjećala bih... i Kada bih se brinula/brinuo o tetoviranom pacijentu osjećala/osjećao bih... hi-kvadrat iznosi 7,05, granični hi-kvadrat 7,815 (5\%).

- Na pitanje Imate li jednako mišljenje o vidljivim tetovažama na medicinskim sestrama i medicinskim tehničarima?, pacijenti su podijeljeni u dvije skupine. Njih ukupno 50 $\%$ odobrava, $48 \%$ ne odobrava, dok $2 \%$ pacijenata ne odobrava tetovaže na medicinskim sestrama, ali ih odobrava na medicinskim tehničarima. Što se tiče stavova medicinskih sestara o vidljivim tetovažama na pacijentima, njih $98 \%$ odobrava, a $2 \%$ ne odobrava tetovaže. Dobiven rezultat hi-kvadrata je 25,10, granični hi-kvadrat (5\%).

- S tvrdnjom Tetovaže odražavaju ukus i karakter medicinske sestre / medicinskog tehničara gotovo podjednak broj pacijenata u potpunosti se slaže (37\%) i u potpunosti se ne slaže (39\%). Ukupno $13 \%$ pacijenata djelomično se slaže, niti se slaže niti se ne slaže $7 \%$ ispitanih pacijenata, djelomično se ne slaže njih $4 \%$. S tvrdnjom Tetovaže odražavaju ukus i karakter pacijentice/pacijenta u potpunosti se slaže $31 \%$ medicinskih sestara / tehničara, djelomično se slaže njih $26 \%$, uopće se ne slaže $26 \%$, niti se slaže niti se ne slaže $12 \%$, a djelomično se ne slaže 5 $\%$ ispitanih medicinskih sestara / tehničara. Hi-kvadrat iznosi 3,68, granični hi-kvadrat (5\%) 9,488.

- S tvrdnjom S medicinskom sestrom / medicinskim tehničarom s tetovažom mogu otvoreno razgovarati isto kao $i$ $s$ medicinskom sestrom / medicinskim tehničarom bez tetovaže većina se pacijenata u potpunosti slaže (85\%), uopće se ne slaže njih $7 \%$, djelomično se ne slaže $4 \%$, a neodlučnih je $4 \%$. S istom tvrdnjom koja se odnosi na pacijente velika se većina medicinskih sestara / tehničara u potpunosti slaže (95\%), a djelomično se slaže 5 \%. Hi-kvadrat iznosi 7,02, granični hi-kvadrat (5 \%) 9,488.

- S tvrdnjom Prema medicinskoj sestri / medicinskom tehničaru s tetovažom osjećam jednaku dozu poštovanja kao prema medicinskoj sestri / medicinskom tehničaru bez tetovaže većina se pacijenata u potpunosti slaže (78\%), djelomično se slaže $11 \%$ ispitanih pacijenata, niti se slaže niti se ne slaže $9 \%$, a uopće se ne slaže njih $2 \%$. S istom tvrdnjom koja se odnosi na pacijente sve ispitane medicinske sestre / medicinski tehničari u potpunosti se slažu. Hi-kvadrat iznosi 8,56, granični hi-kvadrat (5\%) 9,488 .

- S tvrdnjom Pored medicinske sestre / medicinskog tehničara s tetovažom osjećam se jednako sigurnim (zaštićenim) kao pored medicinske sestre / medicinskog tehničara bez tetovaže većina se pacijenata u potpunosti slaže (85 $\%)$, u potpunosti se ne slaže $9 \%$, djelomično se ne slaže $4 \%$, niti se slaže niti se ne slaže $2 \%$ ispitanih pacijenata. Gotovo sve ispitane medicinske sestre / medicinski teh- ničari slažu se s navedenom tvrdnjom koja se odnosi na pacijente (98 \%), a $2 \%$ ispitanih djelomično se slaže. Hikvadrat iznosi 5,62, granični hi-kvadrat (5\%) 9,488.

- S tvrdnjom Medicinska sestra / medicinski tehničar s tetovažom impulzivnija/i je od medicinske sestre / medicinskog tehničara bez tetovaže većina se ispitanih pacijenata u potpunosti ne slaže (65\%), niti se slaže niti se ne slaže njih $17 \%$, djelomično se ne slaže $7 \%$, potpuno se slaže $7 \%$ te se djelomično slaže $4 \%$ ispitanih pacijenata. Većina ispitanih medicinskih sestara / tehničara s istom tvrdnjom koja se odnosi na pacijente u potpunosti se ne slaže (64\%), djelomično se slaže $14 \%$ ispitanih, djelomično se ne slaže $10 \%$, niti se slaže niti se ne slaže $10 \%$, a potpuno se slaže njih $2 \%$.

- S tvrdnjom Medicinska sestra / medicinski tehničar s tetovažom sigurnija/i je u sebe nego medicinska sestra / medicinski tehničar bez tetovaže većina ispitanih pacijenata u potpunosti se ne slaže (76 \%), potpuno se slaže $9 \%$, djelomično se slaže $9 \%$, niti se slaže niti se ne slaže 4 $\%$, djelomično se ne slaže $2 \%$. Većina ispitanih medicinskih sestara / tehničara s istom tvrdnjom koja se odnosi na pacijente uopće se ne slaže (60\%), niti se slaže niti se ne slaže $24 \%$, djelomično se slaže $7 \%$, potpuno se slaže $7 \%$, a djelomično se ne slaže njih $2 \%$. Hi-kvadrat iznosi 4,20, granični hi-kvadrat 9,488 (5\%).

- S tvrdnjom Medicinska sestra / medicinski tehničar s tetovažom prihvaćenija/i je u svojoj okolini od medicinske sestre / medicinskog tehničara bez tetovaže većina ispitanih pacijenata uopće se ne slaže (67\%), niti se slaže niti se ne slaže $15 \%$, djelomično se slaže $7 \%$, djelomično se ne slaže $7 \%$, a u potpunosti se slaže $4 \%$ ispitanih pacijenata. Većina ispitanih medicinskih sestara / tehničara $\mathrm{s}$ istom tvrdnjom koja se odnosi na pacijente uopće se ne slaže (60\%), niti se slaže niti se ne slaže njih $31 \%$, djelomično se slaže $5 \%$, djelomično se ne slaže ili se u potpunosti slaže $2 \%$ ispitanih medicinskih sestara / tehničara. Hi-kvadrat iznosi 1,83, granični hi-kvadrat (5 \%) 9,488 .

Na temelju svih dobivenih rezultata hi-kvadrata koje smo usporedili s graničnim hi-kvadratom (5 \%) zaključili smo da postoji statistički značajna razlika na razini statističke značajnosti $p<0,05$ u stavovima između pacijenata i medicinskih sestara / tehničara samo u odgovorima na tvrdnje Imam jednako mišljenje o vidljivim tetovažama na medicinskim sestrama i medicinskim tehničarima... i Imam jednako mišljenje o vidljivim tetovažama na pacijenticama i pacijentima....

\section{Rezultati ispitivanja poznavanja teorije o tetovažama}

- Za tvrdnju Tetoviranje se kroz povijest koristilo u svrhu otklanjanja boli bilo je više točnih odgovora među pacijentima (30\%), a među medicinskim sestrama / tehničarima bilo je $14 \%$ točnih odgovora.

- Na tvrdnju Tetoviranje se danas ne koristi za postupke vezane uz medicinu točan odgovor dalo je ukupno $63 \%$ pacijenata i $83 \%$ medicinskih sestara / tehničara. 
- Na tvrdnju Tetovirati se ne bi smjeli oboljeli od epilepsije i tetanusa netočno je odgovorilo $70 \%$ pacijenata, a $74 \%$ medicinskih sestara / tehničara dalo je točan odgovor.

- Na tvrdnju Moguće nuspojave tetoviranja su tetanus, HIV virus, hepatitis i herpes $85 \%$ pacijenata i $97 \%$ medicinskih sestara / tehničara odgovorilo je točno.

- Na tvrdnju Tetovaže mogu uzrokovati određene poteškoće prilikom određenih medicinsko-dijagnostičkih postupa$k a$ točno je odgovorilo $54 \%$ pacijenata i $64 \%$ medicinskih sestara / tehničara.

- Na tvrdnju Tetovirane osobe mogu biti dobrovoljni darivatelji krvi točno je odgovorilo $80 \%$ pacijenata i $74 \%$ medicinskih sestara / tehničara.

\section{Testiranje hipoteza}

Testiranje hipoteze 1: Medicinske sestre / medicinski tehničari imaju pozitivniji stav prema pacijentima s tetovažom od pacijenata prema medicinskim sestrama / tehničarima s tetovažom. Na temelju dobivenog hi-kvadrata koji iznosi 6,21 i usporedbe s graničnim hi-kvadratom (5\%) koji iznosi 5,992 dolazimo do zaključka da postoji statistički značajna razlika.

Testiranje hipoteze 2: Pacijenti s jednom tetovažom ili više tetovaža imaju pozitivniji stav prema medicinskim sestrama / tehničarima s tetovažom od pacijenata koji nemaju tetovažu. Na temelju dobivenog hi-kvadrata koji iznosi 1,65 i usporedbe s graničnim hi-kvadratom (5 \%) koji iznosi 5,992 možemo zaključiti da ne postoji statistički značajna razlika.

Testiranje hipoteze 3: Pacijenti s višom ili visokom stručnom spremom imaju pozitivniji stav prema medicinskim sestrama / tehničarima od pacijenata koji imaju srednju stručnu spremu ili su kvalificirani ili nekvalificirani radnici. Na temelju dobivenog hi-kvadrata koji iznosi 0,94 i usporedbe s graničnim hi-kvadratom (5 \%) koji iznosi 5,992 dolazimo do zaključka da ne postoji statistički značajna razlika.

Testiranje hipoteze 4: Osobe koje žive u gradu imaju pozitivniji stav prema pacijentima ili medicinskim sestrama / tehničarima s tetovažom od onih koji žive u predgrađu ili na selu. Na temelju dobivenog hi-kvadrata koji iznosi 3,95 i usporedbe s graničnim hi-kvadratom koji iznosi 9,488 (5 \%) možemo zaključiti da ne postoji statistički značajna razlika.

\section{Rasprava}

Rezultati istraživanja pokazuju da su tetovaže kod zdravstvenih djelatnika sve prisutnije i slijede pozitivan trend tetoviranja. Koch i sur. navode da je u SAD-u Body art popularan među mladim generacijama, u dobi od 18 do 25 godina prisutnost tetovaža je od $20 \%$ do $25 \%$, a piercinga od $35 \%$ do $50 \%$ [9]. Sukladno navedenim podacima, rezultati ovog istraživanja pokazuju da među mlađim zdravstvenim djelatnicima u dobi od 18 do 29 godina postoji pozitivan stav o tetovažama, naime, četvrtina ispitanih zdravstvenih djelatnika razmišlja o tetoviranju. U provedenom istraživanju pokazalo se da postoji značajna razlika u stavovima između medicinskih sestara / tehničara i pacijenata prema tetoviranim osobama. lako je stigmatizacija tetoviranih zdravstve- nih djelatnika minimalna, ona ipak postoji. Razlog tomu su predrasude koje pacijenti imaju o samim tetovažama, a odgovorima na tvrdnju Ne bih htjela/htio da mi ta/taj medicinska sestra / medicinski tehničar prilazi može se naslutiti kako pacijenti na temelju vanjskog izgleda zdravstvenog djelatnika i postojanja vidljive tjelesne tetovaže zaključuju da profesionalne kvalitete nisu dostatne za skrb. Rezultati istraživanja pokazuju da se na temelju vizualne percepcije donosi mišljenje o kompetencijama zdravstvenih djelatnika. Thomas i sur. istaknuli su da su medicinske sestre koje imaju neki tjelesni ukras (vidljivu tetovažu ili piercing) manje vješte i brižne [10]. Ovim smo istraživanjem utvrdili postojanje razlike (iako nije značajna, ipak postoji) u odobravanju tetovaža na zdravstvenim djelatnicima s obzirom na spol. $U$ istraživanju Westerfield i sur. pacijenti su također imali nepovoljniji stav o tetovažama na medicinskim sestrama nego na medicinskim tehničarima [11].

U provedenom istraživanju s tvrdnjom Tetovaže odražavaju ukus i karakter medicinske sestre / medicinskog tehničara u potpunosti se slaže $37 \%$ i u potpunosti se ne slaže $39 \%$ ispitanih pacijenata što pokazuje podijeljenost mišljenja. U istraživanju Westerfield i sur. $62 \%$ pacijenata navodi da su tetovirani zdravstveni djelatnici jednako pristupačni i otvoreni kao i oni koji nemaju tetovažu na tijelu [11].

Većina pacijenata (85 \%) u našem istraživanju navodi da može otvoreno razgovarati s medicinskom sestrom / medicinskim tehničarom s tetovažom i bez tetovaže. Čak 95 \% medicinskih sestara / tehničara provedenog istraživanja odgovara da može otvoreno razgovarati s tetoviranim pacijentom/pacijenticom kao i s pacijentom/pacijenticom bez tetovaže. Dobiveni rezultat potvrda je da ne postoji diskriminacija pacijenata od zdravstvenih djelatnika kako sestrinska profesija i nalaže. Kada je riječ o osjećaju sigurnosti, 85 \% pacijenata koji su sudjelovali u istraživanju osjeća sigurnost pored tetoviranog zdravstvenog djelatnika, dok u istraživanju Westerfield i sur. isto osjeća 65 \% [11]. Pfeifer [12] ističe da se medicinske tehničare $s$ vidljivim tetovažama rijetko percipira s više profesionalnih kompetencija nego njihove netetovirane kolege te da pacijenti smatraju tetovirane medicinske sestre impulzivnijima. Po njihovu mišljenju takve medicinske sestre traže više pažnje nego njihovi kolege bez vidljivih tetovaža. Medicinske sestre s piercingom doživljavane su kao manje profesionalne, manje samopouzdane, manje pristupačne i manje efikasne [12]. U našem istraživanju $9 \%$ pacijenata navodi da se ne osjeća sigurno pored tetovirane medicinske sestre / medicinskog tehničara. lako ovim istraživanjem potvrđujemo da se manji postotak pacijenata osjeća nesigurno u prisutnosti tetoviranih zdravstvenih djelatnika, to nije zanemariv podatak. Zdravstveni djelatnici trebaju uzeti u obzir ovaj podatak te pokušati pacijentovo okruženje učiniti prihvatljivijim. Prema istraživanju Williams i sur. provedenom na studentima sestrinstva posjedovanje tetovaže predstavlja probleme u akademskim ustanovama, ali i u klinikama. Zaključci istraživanja isto tako navode preporuke studentima sestrinstva za prekrivanje vidljivih tetovaža [13].

Pojmovi impulzivnosti i povećane sigurnosti u sebe često se povezuju s osobama koje posjeduju tetovaže. Ukupno $7 \%$ pacijenata našeg istraživanja u potpunosti se slaže $s$ tvrdnjom da je medicinska sestra / medicinski tehničar s 
tetovažom impulzivnija/i, dok se većina pacijenata (65\%) s ovom tvrdnjom ne slaže. S obzirom na rezultate istraživanja, možemo zaključiti da impulzivnost nije karakterna osobina koja bi se mogla pripisati medicinskim sestrama i medicinskim tehničarima. Mišljenja medicinskih sestara i medicinskih tehničara gotovo su identična mišljenjima pacijenata. Naime, 64 \% zdravstvenih djelatnika ne smatra da su pacijenti s tetovažom impulzivniji od onih bez tetovaže. Samo $2 \%$ ispitanih zdravstvenih djelatnika slaže se s ovom tvrdnjom. Armstrong i sur. u svom radu ukazuju na to da je kod ispitanika koji posjeduju jednu tetovažu i manje od četiri piercinga prisutno blagostanje, dok su ispitanici s četiri tetovaže i više tetovaža i/ili sedam i više piercinga skloni impulzivnijim i rizičnijim ponašanjima [14].

Odgovarajući na tvrdnje o poznavanju teorije o tetovažama, rezultati istraživanja pokazuju da se tetovaže koriste za uklanjanje boli (30\% ispitanih pacijenata) i da se tetoviranje danas ne koristi samo za postupke vezane za medicinu (83\% medicinskih sestara / tehničara). lako se tetoviranje ne koristi u terapijske svrhe, neki oblici tetoviranja služe u rekonstrukcijskoj kirurgiji. Prema podacima istraživanja koje su proveli Clarkson i sur. ova vrsta ukrašavanja tijela koristi se kod tetoviranja areola (tamna pigmentirana koža oko bradavica) i bradavica nakon radikalne mastektomije. Iskustva pacijenata koji su se podvrgnuli ovakvom načinu tetoviranja pozitivna su i zadovoljavajuća [15].
Medicinske sestre i medicinski tehničari pokazuju veću razinu znanja koje se odnosi na poznavanje nuspojava povezanima s tetoviranjem, određenim poteškoćama koje se mogu javiti prilikom izvođenja medicinsko-dijagnostičkih postupaka kod tetoviranih osoba i mogućnošću tetoviranja osoba oboljelih od epilepsije. Međutim, ipak je zabrinjavajući podatak da samo $64 \%$ medicinskih sestara / tehničara zna da tetovaže mogu uzrokovati poteškoće prilikom određenih medicinsko-dijagnostičkih postupaka. Prema dobivenim rezultatima provedenog istraživanja može se zaključiti da generalno prevladavaju pozitivni stavovi o tetovažama.

\section{Zaključak}

Istraživanjem se nastojao dobiti bolji uvid u stavove medicinskih sestara te pacijenata o vidljivim tetovažama. Rezultati pokazuju da medicinske sestre odobravaju tetovaže na pacijentima te da su stavovi o tetovažama u objema skupinama ispitanika generalno pozitivni. Sociodemografski podaci zastupljeni u istraživanju nisu se pokazali relevantnima, odnosno ne utječu na odobravanje tetovaža. Što se tiče ukupnog teorijskog znanja o tetovažama, medicinske su sestre pokazale višu razinu znanja o tetovažama.

\section{Nema sukoba interesa}

\section{Authors declare no conflict of interest}

\section{Literatura / References}

[1] Bočina I. Narodni zdravstveni list. Tetovaže i piercing: Ukras ili užas. Dostupno na: http://www.zzjzpgz.hr/nzl/58/tetovaze-uzas-ili-ukras. htm Pristupljeno: 4. 12. 2020.

[2] Drvo znanja: enciklopedijski časopis za mladež. Tetovaža: crtati po tijelu. 2003; 67: 46-51.

[3] Tetoviranje. Available from: https://hr.wikipedia.org/wiki/Tetoviranje. Pristupljeno: 4. 12. 2020

[4] Osnovnoškolci - Tetoviranje-Portal za škole. Dostupno na: http:// www.skole.hr/dobro-je-znati/osnovnoskolci?news id=456. Pristupljeno: 4. 12. 2020.

[5] Đurđić L, Dimitrijević B. Emocionalni profil i doživljaj tela kod osoba s tetovažom. Godišnjak za psihologiju. 2008; 5 (6-7): 169-86.

[6] Što tetovaže govore o vama. Dostupno na: https://www.elle.hr/lifestyle/sto-tetovaze-govore-o-vama/ Pristupljeno: 5. 12. 2020.

[7] HKMS. Lopar, A, Hodžić, A. Zdravstveni djelatnici i tetovaže-da ili ne? Available from: https://edu.hkms.hr/mod/forum/discuss.php?d=58 Pristupljeno: 5. 12. 2020.

[8] Martinec R. Doživljaj slike tijela u kulturno-povijesnom i umjetničkom kontekstu. Jahr. 2013; 4 (2): 843-56

[9] Koch JR, Roberts $A E$, Armstrong ML, Owen DC. Body art, deviance, and American college students. Soc Sci J. 2010; 47: 151-61. doi: 10.1016/j.soscij.2009.10.001

[10] Thomas CM, Ehret A, Ellis B, Colon-Shoop S, Linton J, Metz S Perception of Nurse Caring, Skills, and Knowledge Based on Appearance. J Nurs Adm. 2010; 40 (11): 489-97. doi: 10.1097/ NNA.0b013e3181f88b48

[11] Westerfield HV, Stafford AB, Speroni KG, Daniel MG. Patients' Perceptions of Patient Care Providers With Tattoos and/or Body Piercings. J Nurs Adm. 2012; 42 (3): 160-4. doi: 10.1097/NNA.0b013e31824809d6

[12] Pfeifer GM. Attitudes toward piercings and tattoos: Does body modification suggest a lack of professionalism, or is it simply freedom of expression?. Am J Nurs. 2012; 112 (5): 15. doi: 10.1097/01. NAJ.0000414303.32050.99

[13] Williams BM, Wright C, Leigh KH, Armstrong B, Kelley S. Tattoos in Nursing: Do We Practice What We Preach?. J Christ Nurs. 2019; 36 (1): 38 41. doi: $10.1097 /$ CNJ.0000000000000496

[14] Armstrong ML, Tustin J, Owen DC, Koch JR, Roberts AE. Body art education: the earlier, the better. J Sch Nurs. 2014; 30 (1): 12-8. doi: 10.1016/j.soscij.2009.10.001

[15] Clarkson JH, Tracey A, Eltigani E, Park A. The patient's experience of a nurse-led nipple tattoo service: a successful program in Warwickshire. J Plast Reconstr Aesthet Surg. 2006; 59 (10): 1058-62. doi: 10.1016/j. bjps.2005.09.049

[16] Čordaš I. Mišljenje pacijenata, medicinskih sestara i tehničara o vidljivim tjelesnim tetovažama. Sveučilište u Osijeku. Završni rad; 2018. 